\title{
APPLIED ANALYSIS OF MILK MARKET IN BAHRAIN
}

\author{
Análise aplicada do mercado de leite em Bahrein
}

\author{
Mohammed Al-Mahish'*, Muhammet Yunus Sisman², Raga Elzaki
}

\begin{abstract}
The paper analyzes milk consumption and milk production in the Kingdom of Bahrain by focusing on the forces of demand and supply. The results showed that the demand for milk in Bahrain is price inelastic and imported milk is a complement to domestic milk. Also, domestic milk supply in Bahrain is price inelastic and an increase in imported milk price increases domestic milk production. Furthermore, an increase in domestic income increases thequantity demanded of domestic and imported milk. However, it does not affect domestic milk supply and the prevailing milk prices. Conversely, an increase in alfalfa hay prices decreases domestic milk production and increases milk import.
\end{abstract}

Keywords: milk import; Bahrain; equilibrium displacement model.

\section{RESUMO}

Este trabalho analisa o mercado e o consumo de leite no Reino do Bahrein com foco nas leis da oferta e da procura. Os resultados mostraram que a demanda por leite em Bahrein é inelástica ao preço e o leite importado é um complemento ao produzido internamente. Além disso, a oferta por leite doméstico em Bahrein é inelástica ao preço e o aumento do leite importado gera aumento na produção de leite doméstico. Além disso, com o aumento da renda interna ocorre o aumento da demanda por leite doméstico e importado. No entanto, isto não afeta a oferta por leite doméstico e os preços. Por outro lado, o aumento no preço de feno e alfafa diminui a produção de leite doméstico e aumenta a importação.

1 King Faisal University, College of Agriculture and Food Science, Department of Agribusiness and Consumer Science, Hofuf, Saudi Arabia. E-mail:mohammed_9m@yahoo.com

2 Dumlupınar University, Faculty of Economics and Administrative Sciences, Kütahya, Turkey.

3 University of Gezira,Faculty of Animal Production,Department of Rural Economics and Development, Wadmedan, Sudan.

* Corresponding author/Autor para correspondência. 
Palavras-chave: importação de leite; Bahrein; modelo de deslocamento de equilíbrio.

\section{INTRODUCTION}

Bahrain is a small open and improved industrial economy with a relatively small population. The Gross Domestic Product (GDP) in Bahrain was 35.31 billion US dollars in 2017 (CBB, 2018), meanwhile Bahrain has been pursuing the policies of sustainable and diversified economic growth (NAKIBULLAH, 2018). The milk supply in Bahrain is composed of two sources: domestic production and milk imports. Furthermore, Bahrain is selfinsufficient regarding milk and milk products. Hence, it is trying to fill the deficiency by importing milk products.

Many studies and reports indicate that Bahrain produces few food products mostly crops, vegetables, poultry and milk products, with most food stuffs imported (MUSAIGER, 1989, USDA, 2018, FAO, 2018; NAKIBULLAH, 2018). Regarding the milk imported to Bahrain from Saudi Arabia, it is estimated to reach $\$ 17$ million in 2016; the sales of milk to Bahrain from Saudi Arabia in 2016 increased by $10.6 \%$ in 2015. Saudi Arabia's exports value to Bahrain is amounted to $\$ 809.4$ million $(5.5 \%$ of its overall imports), while the dairy, eggs, and honey are valued at an estimated \$118.4 million (UNIT, 2018).

Globally, the total milk imports increased hardly by $1.7 \%$ in 2017 over 2016 (FAO, 2018) and the dairy trade faces the highest level of import protection and export subsidies in comparison to the other agricultural commodity categories in theworld (DIAO et al., 2001). A study conducted in Australia showed that international and domestic dairy prices have become quite volatile, and the study attributed this to dynamic supply-demand response together with the reliance of dairy production on inputs such as grains, whose price has also been volatile (PWC, 2011).

A study performed by Blaskó (2012) stated that the international market trends and the established international prices influence domestic prices through foreign trade, whereas Horvath; Mikó (2016) revealed that milk prices have fallen mainly because of greater supply on world markets. Davis et al. (2018) confirms that dairy industries in Southeast Asia are small and produce less than the domestic market demands. Atsbeha et al. (2015) investigated the milk supply response by estimating the adjustment in quasi-fixed factors, which is limited in the short-run, and indicated that milk component supply responds to price incentives in the short-run. Komaki; Penzer (2005) considered that the price inelasticity of milk supply is relatively due to production technology and the lower prices do not have a great role in decreasing the supply of milk under inelastic production. Tonini; Jongeneel (2008) proposed that the own-price supply elasticities for milk are rather similar across countries and over time and confirmed that the permanent pasture had a negative impact on milk supply.

Jones; Blayney (2014) used the model of the Central Bureau of Statistics (CBS) demand system combined with the almost ideal demand system (AIDS) model for measuring the milk import across KoreaUnited States. Their outcomes indicated that the cross-price elasticities were positive and statistically insignificant. Also, both the short-run and long-run own-price elasticities of demand were negative and inelastic for most of the source of studied countries. An additional study achieved by Song; Sumner (1999) in Korea showed a positive sign of 
supply and income elasticity and negative sign of price elasticity of demand for fluid milk and other dairy products. Song; Sumner (1999) confirmed that the supply shifts are constrained by feed prices and environmental pressures, which are assumed to offset technical improvements, and thus, domestic production increases only by movements up the supply curve, while Anderson et al. (2006) stated that the import demand curve is downward sloping. Additionally, More (2009) indicated that in wealthy countries, there have been substantial shifts in demand for dairy products.

Bozica et al. (2012) indicated that milk supply is getting more responsive regardingboth milk and feed prices. However, Roemen (1993) argued that in the long-term, milk supply elasticity fits out to be taking a value which lies noticeably below the turning point between an elastic and inelastic reaction (0.765). Komaki; Penzer (2005) studied the relationship between changes in dairy policy and changes in the price elasticity of the supply of raw milk in Japan, and they found that political regulation of supply stabilizes the price elasticity in Japan. Furthermore,
Chizari et al. (2018) estimated a positive ownprice supply elasticity of raw milk, whereas Atsbeha et. al. (2015) revealed that all ownprice elasticities of milk supply are positive for outputs and negative for inputs. Kumar et al. (2014) found that a major reason behind the rising demand for milk is its substantially higher income elasticity of demand, which is greater in rural than urban areas. Mdoe; Wiggins (1996) stated that the domestic demand for milk was increasingly met by imports of dairy products and the estimated income elasticity of demand for whole milk was slightly greater than unity in rural areas.

This paper aimed to examine milk demand and milk supply in Bahrain descriptively by using the graphical method and quantitatively through the equilibrium displacement model (EDM).

\section{MATERIALS AND METHODS}

Milk producers in Bahrain faced fierce competition from other Gulf Cooperation Council - GCC producers, especially producers from Saudi Arabia (GULF INDUSTRY ONLINE, 2001). When Bahrain dairy pro-

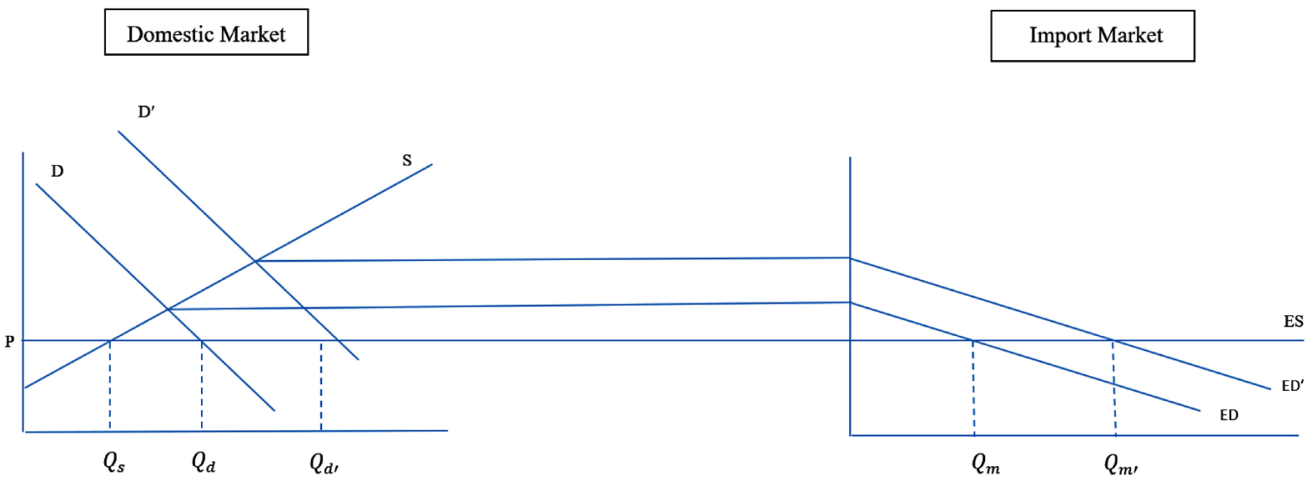

Source: Authors.

Note: P, D, S, $Q_{s}, Q_{d}, Q_{m}$, ED, and ES stand for price, demand, supply, quantity supplied, quantity demanded, quantity imported, excess demand, and excess supply.

Figure 1 - Representation of the milk market equilibrium of the kingdom of Bahrain. 
ducers set their milk price, they had to take into account the price of imported milk from Saudi producers. Since Bahrain's economy was a small open economy, which could not affect the prevailing milk price, we could say that Bahraini dairy producers faced a perfectly elastic import supply curve. From Figure 1, it is clear that the domestic milk market supply comes from two sources, domestic supply and the imports market.

Figure 1 shows that an increase in domestic demand, due to a shift in domestic demand shifters, such as an increase in income, did not affect the prevailing price. Similarly, an increase in supply shifter, such as an increase in domestic milk production facilities, would have no effect on the prevailing milk price.

\section{Theoretical Model}

The equilibrium displacement model was used to analyze the dairy sector in Bahrain; Davis (2001) confirmed that the popular modelling approach in agricultural economics that has received recent methodological attention is the equilibrium displacement model (EDM).

$Q_{d}=D(P, I) \quad\left(\frac{\partial D}{\partial P}<0, \frac{\partial D}{\partial I}>0\right)$

$Q_{S}=S(P, L) \quad\left(\frac{\partial S}{\partial P}>0, \frac{\partial S}{\partial L}<(0)\right.$

$Q_{m}=M(P) \quad\left(\frac{\partial M}{\partial P}<0\right) \quad\left(\frac{\partial M}{\partial P}<0\right)(3)$

$Q_{d}=Q_{s}+Q_{m} \quad$ (Equilibrium Condition)

Where $Q_{s}, Q_{d}$ and $Q_{m}$ are the quantity demand, quantity supplied, and quantity imported, respectively. $P, I$, and $L$ are price of milk, income, and price of alfalfa hay that was used as an input in domestic milk production. The model contained four endogenous variables $Q_{s}, Q_{d}, Q_{m}$ and $P$ and two exogenous variables $I$ and $L$.

We then expressed equations (1)-(4) in EDM form as below:

$$
\begin{aligned}
& Q_{d}^{*}=\eta_{p} P^{*}+\eta_{I} I^{*} \\
& Q_{s}^{*}=\varepsilon_{\mathrm{p}} \mathrm{P}^{*}+\varepsilon_{L} \mathrm{~L}^{*} \\
& Q_{m}^{*}=\varepsilon_{m} P^{*} \\
& Q_{d}^{*}=k_{s} Q_{s}^{*}+k_{m} Q_{m}^{*}
\end{aligned}
$$

Where $k_{s}$ is the share of domestic consumption that come from domestic production and $k_{m}$ is the share of domestic consumption that comes from import. $\eta_{p}, \eta_{I}, \varepsilon_{\mathrm{p}}, \varepsilon_{\mathrm{L}}$ are price and income elasticities of milk demand, price elasticities of milk and alfalfa hay supply, respectively. If we solve (5) to (8) simultaneously, we obtain the following expressions:

$P^{*}=\left(\frac{\eta_{\boldsymbol{l}}}{k_{s} \varepsilon_{\mathbf{p}}+k_{m} \varepsilon_{m}-\eta_{p}}\right) I^{*}-\left(\frac{k_{s} \varepsilon_{L}}{k_{s} \varepsilon_{\mathbf{p}}+k_{m} \varepsilon_{m}-\eta_{p}}\right) L^{*}$

$Q_{m}^{*}=\left(\frac{\eta_{I} \varepsilon_{m}}{k_{s} \varepsilon_{\mathrm{p}}+k_{m} \varepsilon_{m}-\eta_{p}}\right) I^{*}-\left(\frac{\varepsilon_{m} k_{s} \varepsilon_{L}}{k_{s} \varepsilon_{\mathrm{p}}+k_{m} \varepsilon_{m}-\eta_{p}}\right) L^{*}$

$Q_{s}^{*}=\left(\frac{\eta_{I} \varepsilon_{\mathrm{p}}}{k_{s} \varepsilon_{\mathrm{p}}+k_{m} \varepsilon_{m}-\eta_{p}}\right) I^{*}+\left(\frac{\varepsilon_{L}\left(k_{m} \varepsilon_{m}-\eta_{p}\right)}{k_{s} \varepsilon_{\mathrm{p}}+k_{m} \varepsilon_{m}-\eta_{p}}\right) L^{*}$

$Q_{d}^{*}=\left(\frac{\eta_{I}\left(k_{s} \varepsilon_{p}+k_{m} \varepsilon_{m}\right)}{k_{s} \varepsilon_{\mathrm{p}}+k_{m} \varepsilon_{m}-\eta_{p}}\right) I^{*}-\left(\frac{\eta_{p} k_{s} \varepsilon_{L}}{k_{s} \varepsilon_{\mathrm{p}}+k_{m} \varepsilon_{m}-\eta_{p}}\right) L^{*}($

Expressions (9) to (12) were good fit for the case of a large importer. However, Since Bahraini dairy producers faced a perfectly elastic supply curve in the import market 
$\left(\varepsilon_{m}=\infty\right)$, expressions (10) to (12) reduce to the following:

$$
\begin{aligned}
& Q_{m}^{*}=\left(\frac{\eta_{I}}{k_{m}}\right) I^{*}-\left(\frac{k_{s} \varepsilon_{L}}{k_{m}}\right) L^{*} \\
& Q_{s}^{*}=\varepsilon_{L} L^{*} \\
& Q_{d}^{*}=\eta_{I} I^{*}
\end{aligned}
$$

Based on equations (13)-(15), we constructed the following comparative statichy potheses:

$$
\begin{aligned}
& \frac{Q_{m}^{*}}{I^{*}}=\frac{\eta_{I}}{k_{m}}>0 \\
& \frac{Q_{m}^{*}}{L^{*}}=-\frac{k_{s} \varepsilon_{L}}{k_{m}}>0 \\
& \frac{Q_{s}^{*}}{I^{*}}=0 \\
& \frac{Q_{s}^{*}}{L^{*}}=\varepsilon_{L}<0 \\
& \frac{Q_{d}^{*}}{I^{*}}=\eta_{I}>0 \\
& \frac{Q_{d}^{*}}{L^{*}}=0 \\
& \frac{P^{*}}{I^{*}}=0 \\
& \frac{P^{*}}{L^{*}}=0
\end{aligned}
$$

Hypotheses (16)-(23) briefly stated that the rise in income in Bahrain increased domestic milk consumption and milk import. However, income increases would have no influence on domestic milk production and milk price. Furthermore, an increase in alfalfa hay price would decrease domestic milk production, and consequently, milk import would decrease. On the other hand, changes in alfalfa price related to domestic milk production would have no impact on domestic milk consumption and milk price.

Milk prices were generally determined by the situation of demand, supply and the agricultural policy system in addition to the diversity of milk prices between the countries gave a first impression of how national and international trade and market policies were affecting the dairy markets (HEMME; DEEKEN, 2005).

The Almost Ideal Demand System (AIDS) was used in order to estimate the required demand elasticities to calibrate the EDM model. The AIDS model was selected since it is widely used to in the economic literature to estimate demand elasticities for agricultural products. The AIDS model was expressed as below:

$$
W_{i}=a_{i}+\beta_{i} \ln \left(\frac{X}{P}\right)+\sum_{j=1}^{n} \gamma_{i j} p_{j}+u_{i}
$$

Where $W_{i}$ is the budget share on commodity i, $X$ is the total expenditures on all the commodities, and $p_{j}$ is the price of commodity $j$. Moreover, $P$ is translog price index defined as:

$$
\begin{aligned}
& \ln P=a_{0}+\sum_{i=1}^{n} a_{i} \ln p_{i}+ \\
& 1 / 2 \sum_{i=1}^{n} \sum_{j=1}^{n} \gamma_{i j} \ln p_{i} \ln p_{j}
\end{aligned}
$$

Since the translog price index was a nonlinear price index, it was often approximated by a linear price index, which results in a linear approximate almost ideal demand 
system (LA-AIDS). To avoid simultaneity problem associated with Stone price index (EALES; UNNEVEHR, 1988), this paper used the corrected Stone price index (MOSCHINI, 1995) expressed as follows:

$$
\ln P_{t}^{*}=\sum_{t=1}^{n} W_{i t} \ln \left(\frac{p_{i t}}{p_{i}^{0}}\right)
$$

$p_{i}^{0}$ was the price of commodity $i$ in the base period. The parametric restrictions on the LA-AIDS model were:

Homogeneity: $\sum_{j} \gamma_{i j}=0$

Adding-up: $\sum_{i} \gamma_{i j}=0, \sum_{i} \beta_{i}=0, \sum_{i} a_{i}=1$

Symmetry: $\gamma_{i j}=\gamma_{j i}$

The system of demand equations in this paper included domestic milk, imported milk, and poultry. Poultry was added because butter milk was often consumed with poultry products, especially during lunch time. Thus, poultry was expected to be a complement item in milk consumption. The Marshallian price elasticities for the LA-AIDS model were computed as below:

$$
e_{i j}=-\delta_{i j}+\left(\frac{\gamma_{i j}}{W_{i}}\right)-\left(\frac{\beta_{i}}{W_{i}}\right) W_{j}
$$

Where $\delta$ is Kronecker delta that equals 1 for $\mathrm{i}=\mathrm{j}$ and 0 otherwise. The expenditure elasticity is computed as follow:

$$
\eta_{i}=1+\left(\frac{\beta_{i}}{w_{i}}\right)
$$

Since the available data was time series data, the first step was to conduct a unit root test. The augmented Dickey Fuller (ADF) was conducted on milk shares, milk prices, and total expenditures. The results of the augmented Dickey Fuller (available upon request) test fail to reject the null hypothesis of a unit root. However, all the variables were differenced stationary I(1). Thus, this paper used an error corrected AIDS model, which was used in the economics literature to estimate demand elasticities in the case of non-stationary variables (KARAGIANNIS et al., 2000; NZUMA; SARKER, 2010; SINGH et al., 2011). The error corrected AIDS model was specified as below:

$$
\Delta W_{i}=\theta_{i} \Delta W_{i-1}+\beta_{i} \Delta \ln \left(\frac{X}{P}\right)+
$$

$$
\sum_{j=1}^{n} \gamma_{i j} \Delta p_{j}+\lambda u_{i-1}+\varepsilon_{i}
$$

Where is the error correction term that was expected to be negative and $\Delta$ is the difference operator. The error corrected AIDS was selected because it is an efficient estimator in case of small samples (NZUMA; SARKER, 2010).

On the other hand, the required supply elasticities to calibrate the EDM model were estimated the following supply:

$\ln Q_{s}=\beta_{0}+\beta_{1} \ln P_{d}+\beta_{2} \ln P_{m}+$

$\beta_{3} \ln P_{a l f}+\beta_{4} \ln$ labor

Where are the prices of domestic milk, imported milk, and alfalfa hay. Due to the unavailability of alfalfa hay price data in Bahrain, and considering the fact that Bahrain is an importing country of alfalfa hay, we used the alfalfa hay price index as reported from the USDA.

\section{RESULTS AND DISCUSSION}

The data on milk domestic quantity (in liter), imported milk quantity (in liter), milk 
value in Bahraini Dinar are obtained from Bahrain open data portal (http://www.data. gov.bh/en). The data is annual data from 2000 to 2016. Table 1 shows descriptive statistics of the key variables of the study.

Since all the variables are I(1), we will test for cointegration using the residuals-based approach of Engle; Granger (1987). This method is a two-step method that involves estimating the LA-AIDS model as specified in equation (24), and testing if the residuals are $\mathrm{I}(0)$ in the first step. The cointegration test will be performed using Philips-Perron (PP) cointegration test since it is an ideal test in small samples (NZUMA; SARKER, 2010). The results of the PP test as shown in Table 2 reject the null hypothesis of no cointegration at the five percent level.

Since the variables are cointegrated in the long run, we then estimate the error corrected LA-AIDS model as specified in equation (29). The model was estimated using seemingly unrelated regression method, and the poultry equation was dropped to avoid singularity in the variance-covariance matric.

The model was estimated with symmetry and homogeneity imposed in the estimation. The estimated parameters of the error corrected LA-AIDS model is reported in Table 3.

Table 3 shows that the estimated error correction term is significant and has the expected negative sign. The short-run elasticities are obtained using formulas 27 and 28 . On the other hand, the long-run estimates are obtained as a result of dividing the negative of the short-run estimates on the error correction term. Table 4 shows the estimated short-run and long-run elasticities.

The results show that the own price elasticities in the short-run and in the longrun for both the domestic milk and imported

Table 1 - Descriptive statistics of the key variables

\begin{tabular}{lccccc}
\hline \multicolumn{1}{c}{ Variable } & Average & Maximum & Minimum & Range & $\begin{array}{c}\text { Standard } \\
\text { Deviation }\end{array}$ \\
\hline $\begin{array}{l}\text { Per capita milk consumption } \\
\text { (L/person) }\end{array}$ & 0.067 & 0.106 & 0.033 & 0.073 & 0.018 \\
Domestic milk value (L) & 2562.29 & 3810 & 1860 & 1950 & 565 \\
Imported milk value (L) & 10817 & 28578 & 4085 & 24493 & 7962 \\
$k_{s}^{*}$ & 0.313 & 0.466 & 0.165 & 0.301 & 0.082 \\
$k_{m}^{*}$ & 0.687 & 0.834 & 0.534 & 0.3001 & 0.082 \\
\hline
\end{tabular}

Source: Authors' Calculation.

* $k_{s}$ is share of domestic consumption that comes from domestic production and $k_{m}$ is the share of domestic consumption that comes from import.

Table 2 - Phillips-Perron cointegration test*

\begin{tabular}{ccccc}
\hline Series & Rho & Pr $<$ Rho & Tau & Pr $<$ Tau \\
\hline Domestic Milk & -15.552 & 0.0014 & -3.978 & 0.0005 \\
Imported Milk & -10.730 & 0.0121 & -3.0315 & 0.0046
\end{tabular}

* Rho and Tau statistics and their significance level $(\mathrm{Pr})$ were used to test the null hypothesis of unit root. 
Table 3 - Estimated parameters of the error corrected LA-AIDS model

\begin{tabular}{ccccccc}
\hline Parameter & $\begin{array}{c}\text { Domestic } \\
\text { Milk }\end{array}$ & $\begin{array}{c}\text { Imported } \\
\text { Milk }\end{array}$ & Poultry & $\boldsymbol{\beta}_{\boldsymbol{i}}$ & $\boldsymbol{\theta}$ & $\boldsymbol{\lambda}$ \\
\hline \multirow{2}{*}{$\gamma_{1 i}$} & 0.100 & $-0.076^{*}$ & -0.024 & -0.002 & $-0.421^{* *}$ & $-0.433^{*}$ \\
& $(0.0619)$ & $(0.040)$ & $(0.049)$ & $(0.077)$ & $(0.151)$ & $(0.227)$ \\
\hline \multirow{2}{*}{$\gamma_{2 i}$} & -- & $0.152^{* * *}$ & $-0.076^{* *}$ & $0.270 * * *$ & -0.057 & $-0.434^{* *}$ \\
& -- & $(0.036)$ & $(0.025)$ & $(0.068)$ & $(0.135)$ & $(0.166)$ \\
\hline
\end{tabular}

$* * *, * *$ and $*$ denote significance level at the one, five, and ten percent level respectively.

Table 4 - Short-run and long-run elasticities

\begin{tabular}{ccccc}
\hline Item & $\begin{array}{c}\text { Domestic } \\
\text { Milk }\end{array}$ & $\begin{array}{c}\text { Imported } \\
\text { Milk }\end{array}$ & Poultry & $\begin{array}{c}\text { Expenditure } \\
\text { Elasticity }\end{array}$ \\
\hline Domestic Milk & -0.372 & -0.470 & -0.147 & $0.989 *$ \\
(Short-run elasticities) & $(0.415)$ & $(0.288)$ & $(0.337)$ & $(0.487)$ \\
\hline Imported Milk & $-0.233 * *$ & $-0.700 * * *$ & $-0.324 * * *$ & $1.529 * * *$ \\
(Short-run elasticities) & $(0.087)$ & $(0.118)$ & $(0.066)$ & $(0.133)$ \\
\hline Domestic Milk & -0.860 & -1.085 & -0.338 & 2.283 \\
(Long-run elasticities) & $(1.141)$ & $(0.900)$ & $(0.772)$ & $(1.736)$ \\
\hline Imported Milk & -0.537 & $-1.611 * *$ & $-0.746 *$ & $3.519 * *$ \\
(Long-run elasticities) & $(0.300)$ & $(0.673)$ & $(0.339)$ & $(1.439)$ \\
\hline
\end{tabular}

$* * *, * *$ and $*$ denote significance level at the one, five, and ten percent level, respectively.

milk have the correct negative sign. The demand for domestic milk is price inelastic in the short-run and in the long-run, while the demand for the imported milk is price inelastic in the short-run and price elastic in the long run. The short-run elasticities show that the imported milk is complement to the domestic milk. Also, the results reveal that the import milkis a complement item in poultry consumption in the short-run and in the longrun. This result is expected sine butter milk in Bahrain is often consumed with poultry during lunch or dinner time. The expenditure/income elasticity shows that domestic milk is normal good in the short-run, and the imported milk is a luxury good in both the short-run and the long-run.
The supply model as specified in equation (30) was estimated using the integrated GARCH method. Table 5 shows the estimated supply elasticity.

Table 5 - Domestic milk supply elasticity

\begin{tabular}{cc}
\hline Variable & Parameter Estimates \\
Intercept & $9.687 * * *(0.138)$ \\
Domestic Milk Price & $0.157 * * *(0.031)$ \\
Imported Milk Price & $0.035 * * *(0.009)$ \\
Alfalfa Hay Price & $-0.068 * * *(0.015)$ \\
\hline Labor & $0.004(0.017)$
\end{tabular}

In an attempt to outline the impact of price and income changes on Bahraini milk 
industry, we employ the partial equilibrium model presented in equations (1)-(23). The model is calibrated using the elasticities estimated in the previous section. To obtain reduced-form elasticities the EDM setting is expressed in matrix notation ${ }^{1}$ as:

$$
\Pi \mathrm{Y}=\Gamma \mathrm{Z}
$$

Where $\Pi$ is a $4 \times 4$ matrix of parameters of endogenous variables, $\mathrm{Y}$ is a $4 \mathrm{x} 1$ vector of endogenous variables as the milk industry model contains 4 endogenous variables. $\Gamma$ is a $4 \times 2$ matrix of parameters for exogenous variables, and $\mathrm{Z}$ is a $2 \times 1$ vector of exogenous variables due to 2 exogenous variables included in the model. $\Pi$ is constructed by using the parameter values for elasticities (price and income elasticities of milk demand, price elasticities of milk and alfalfa hay supplyobtained from the model estimations in the previous section) and market shares for imported milk, domestic milk consumption and production.

Pre-multiplying equation (31) by inverse of $\Pi$ yields a useful solution to identify the reduced form elasticities as follows:

$$
\mathrm{Y}=\mathrm{EZ}
$$

Where $\mathrm{E}=\Pi^{-1} \Gamma$ is a $4 \times 1$ matrix containing the reduced-form elasticities. To obtain the numerical values of reduced form elasticities, corresponding parameters values are assigned in order to calculate the matrix E.

Reduced-form elasticities simulated for the preceding parameter values are presented in Table 6. Results conform to the expected incidence signs. Focusing first on domestic income, findings indicate that rising income levelsstimulatedomestic and import market consumptions as a one-percent increase in income increasing the quantity demanded by 2.28 percent and quantity imported by 3.31 percent. However, an increase in income has an infinitesimal impact on the quantity supplied and the market price.

In the case of the price of alfalfa, as the second exogeneous variable in the model, a one-percent increase in this crop's price lead a 0.031 percent increase in quantity imported.

Table 6 - Reduced-form elasticities for targeted production subsidy

\begin{tabular}{ccc} 
Endogenous & Income & Alfalfa \\
\hline Variables & 2,28 & Price \\
$Q_{D}{ }^{*}$ & $-0,00005$ & $-0,00000$ \\
$Q_{S}{ }^{*}$ & 3,31 & 0,030500 \\
$Q_{M}{ }^{*}$ & $-0,00033$ & 0,00000
\end{tabular}

Note: $Q_{d}, Q_{s}, Q_{m}$, and $P^{*}$ stand for quantity demanded, quantity supplied, quantity exported and equilibrium price.

Conversely, the domestic production is negatively affected from an increase in alfalfa price. A one-percent increase in alfalfa price reduces the quantity supplied by 0.069 percent, a much greater value in comparison with the quantity imported. The results suggest that alfalfaprice changes have no positive or negative effect on the prevailing market prices and domestic consumption.

\section{CONCLUSION}

Since Bahrain is a small importing country, the paper showed through the graphical method that milk producers in Bahrain faced a perfectly elastic import supply curve. This means that changes in domestic demand or supply shifters would not affect the prevailing

3 The approach is adopted from Kinnucan; Myrland (2005). 
milk price. Furthermore, the paper estimated the demand elasticities in Bahrain using an error correction LA-AIDS model. The results showed that the demand for domestic milk and imported milk were price inelastic. The cross-price elasticities of demand showed that imported milk was a complement to domestic milk. This was mainly attributed to the fact that domestic milk consumption outweighs domestic milk production. Moreover, the supply model showed that the domestic milk supply in Bahrain was price inelastic and the increase in imported milk price increased domestic milk production. Also, the reduced form elasticities of the EDM showed that an increase in domestic income increasedthe quantity demanded of domestic milk and quantity imported of milk. On the other hand, domestic income increase had an infinitesimal impact on domestic milk production and the prevailing milk prices. Conversely, an increase in alfalfa hay price decreased domestic milk production and increase milk import.

\section{REFERENCES}

ANDERSON, K.; MARTIN, W.; VALENZUELA, E. The relative importance of global agricultural subsidies and market access. World Trade Review, v. 5, n. 3, p. 357-376, 2006. DOI: 10.1017/ S1474745606002916.

ATSBEHA, D. M.; KRISTOFERSSON, D.; RICKERTSEN, K. Component supply responses in dairy production. European Review of Agricultural Economics, v. 43, n. 2, p. 193-215,2015. DOI: 10.1093/erae/ jbv019.

BLASKÓ, B. Analysis of the producer price of Hungarian raw milk in international comparison. Applied Studies in Agribusiness and Commerce-APSTRACT, v. 6, n. 5, p.
27-32,2012. Available at: http://apstract net/index.php/2015/09/29/analysis-of-theproducer-price-of-hungarian-raw-milk-ininternational-comparison/.

BOZIC, M.; KANTER, C. A.; GOULD, B. W. Tracing the evolution of the aggregate US milk supply elasticity using a herd dynamics model. Agricultural Economics, v. 43, n.5, p. 515-530, 2012. DOI: $10.1111 / \mathrm{j} .1574-$ 0862.2012.00600.x.

CENTRAL BANK OF BAHRAIN - CBB Manama, Bahrain,2018. Available at: https:// www.cbb.gov.bh/ar/page_1.php?p=financial_ sector fact sheet.

CHIZARI, A. H.; SALAMI, H.; SHOKOOHI, Z. Estimating market power in Iranian dairy processing industry with dynamic imperfect competition model. Journal of Agricultural Science and Technology, v. 20, n. 1, p.1-12, 2018.

DAVIS, C. G.; CESSNA, J. G.; BLAYNEY, D. P. Southeast Asia's import demand for skim milk powder: Implications for US exporters. Journal of Dairy Science, v. 101, n. 5, p. 4676-4689, 2018. DOI: 10.3168/jds.201712848.

DAVIS, G. C. Confirmation and falsification of Equilibrium Displacement Models. Annual Meetings of the American Association of Agricultural Economists, Chicago, p. 5-8, 2001. Available at: https://core.ac.uk/ download/pdf/7083336.pdf.

DIAO, X.; SOMWARU, A.; ROE, T. A global analysis of agricultural trade reform in WTO member countries. Economic Development Center Bulletin, Bulletin Number 01-1,2001. Available at: http://ageconsearch.umn.edu/ bitstream/12984/1/edb01-01.pdf. 
EALES, J. S.; UNNEVEHR, L. J. Demand for beef and chicken products: separability and structural change. American Journal of Agricultural Economics, v. 70, n. 3, p. 521532, 1988. DOI: $10.2307 / 1241490$.

ENGLE, R. F.; GRANGER, C. W. Cointegration and error correction: representation, estimation, and testing. Econometrica: Journal of the Econometric Society, v. 55, n. 2, p. 251-276,1987. DOI: 10.2307/1913236.

FOOD AND AGRICULTURE ORGANIZATION OF THE UNITED NATIONS - FAO. Dairy Market Review. Rome. p. 5, 2018. www.fao.org/3/I9210EN/i9210en.pdf.

GULF INDUSTRIES ONLINE. Bahrain throws dairy a lifeline,2001. Available at: http://www.gulfindustryonline.com/ news/1134_Bahrain-throws-dairy-a-lifeline. html.

HEMME, T.; DEEKEN, E. Selected results of the IFCN dairy network milk prices and costs of milk production in 2003. In: CONGRESS, 15th, 2005, Campinas. Anais eletrônicos... Campinas: International Farm Management Association, n. 24274, p. 14-19, 2005.

HORVATH, J.; MIKO, E. Impact of economic environment on herd size and milk production in a dairy cattle farm. Lucrări Ştiințifice Management Agricol, v. 18, n. 1, p. 117122,2016. Available at: http://www.1sma.ro/ index.php/lsma/article/view/941.

JONES, K. G.; BLAYNEY, D. Assessing changes in dairy product import demand: The case of South Korea with implementation of the KORUS FTA. Agribusiness, v. 30, n. 1, p. 74-84.2014. DOI: 10.1002/agr.21370.

KARAGIANNIS, G.; KATRANIDIS, S.; VELENTZAS, K. An error correction almost ideal demand system for meat in Greece. Agricultural Economics, v. 22, n. 1, p. 29-35,2000. DOI: 10.1016/S01695150(99)00035-3.

KINNUCAN, H. W.; MYRLAND, Ø. Effects of income growth and tariffs on the world salmon market. Applied Economics, v. 37 , n. 17 , p. 1967-1978, 2005. DOI: $10.1080 / 00036840500217523$.

KOMAKI, T.; PENZER, J. Estimation of time varying price elasticity in 1970-1997 Japanese raw milk supply by structural time series model. Agricultural Economics, v. 32, n. 1, p. 1-14, 2005. DOI: 10.1111/j.01695150.2005.00001.x.

KUMAR, A.; JOSHI, P. K.; KUMAR, P.; PARAPPURATHU, S. Trends in the consumption of milk and milk products in India: implications for self-sufficiency in milk production. Food security, v. 6, n. 5, p. 719726, 2014. DOI: 10.1007/s12571-014-0376-y.

MDOE, N.; WIGGINS, S. Dairy products demand and marketing in Kilimanjaro Region, Tanzania. Food Policy, v. 21, n. 3, p. 319-336, 1996. DOI: 10.1016/0306-9192(96)00003-6.

MORE, S. J. Global trends in milk quality: Implications for the Irish dairy industry. Irish Veterinary Journal, v. 62, n. 4, p. S514,2009. DOI: 10.1186/2046-0481-62-S4-S5.

MOSCHINI, G. Units of measurement and the Stone index in demand system estimation. American Journal of Agricultural Economics, v. 77, n. 1, p. 63-68,1995. DOI: $10.2307 / 1243889$.

MUSAIGER, A. O. Food labelling regulations in Bahrain. Journal of the Royal Society of Health, v. 109, n. 3, p. 96-97, 1989. DOI: $10.1177 / 146642408910900308$. 
NAKIBULLAH, A. Economic diversification in Bahrain. Applied Economics and Finance, v. 5, n. 5, p. 67-74, 2018. DOI:10.11114/aef. v5i5.3576.

NZUMA, J. M.; SARKER, R. An error corrected almost ideal demand system for major cereals in Kenya. Agricultural Economics, v. 41, n. 1, p. 43-50, 2010. DOI: 10.1111/j.1574-0862.2009.00424.x.

PRICE WATER HOUSE COOPERS - PWC. The Australian Dairy Industry: The Basics, 2011. Available at: https://www.pwc.com.au/ industry/agribusiness/assets/australian-dairyindustry-nov11.pdf.

ROEMEN, J. H. J. The long-term elasticity of the milk supply with respect to the milk price in the Netherlands in the period 19691984. European Journal of Operational Research, v. 69, n. 2, p. 221-237, 1993. DOI: 10.1016/0377-2217(93)90166-K.

SINGH, K; DEY, M. M.; THAPA, G. An error corrected almost ideal demand system for crustaceans in the United States. Journal of International Food \& Agribusiness Marketing, v. 23, n. 3, p. 271-284, 2011. DO I:10.1080/08974438.2011.586925.

SONG, J.; SUMNER, D. A. Dairy demand, supply and policy in Korea: Potential for international trade. Canadian Journal of Agricultural Economics, v. 47, n. 5, p. 133142, 1999. DOI: 10.1111/j.1744-7976.1999. tb00251.x.

TONINI, A.; JONGENEEL, R. Modelling dairy supply for Hungary and Poland by generalised maximum entropy using prior information. European Review of Agricultural Economics, v. 35, n. 2, p. 219 246, 2008. DOI:10.1093/erae/jbn018.

UNITED NATIONS INTERNATIONAL TRADE STATISTICS DATABASE - UNIT. Department of Economic and Social Affairs/ Statistics Division. 2018. Available at: https://comtrade.un.org.

UNITED STATES DEPARTMENT OF AGRICULTURE, FOREIGN AGRICULTURAL SERVICES - USDA, 2018. Available at: https://www.fas.usda.gov/ regions/bahrain. 